\title{
EDWARD BLACK GREENSHIELDS: THE MCGILL CONNECTION
}

\section{By Gordon Burr}

Edward Black Greenshields, Montreal businessman and art collector, was a wealthy denizen of the Square. Mile. The head of Greenshields Ltd., the largest dry goods wholesaler in Canada, he had many links to McGill University as a student, benefactor, member of the Board of Governors and contributor to The University Magazine. This paper is an exploration of Greenshields' benevolent and cultural ties to McGill, primarily during a golden age of University expansion from 1890 to the First World War.

Edward Black Greenshields, riche hornme d'affaires et collectionneur d'oeuvres d'art montrélais, habitait le Square Mile. Président de Greenshields Ltd., le plus important grossiste de mercerie du Canada, iI a entretenu de nombreux rapports avec l'Université McGill comme étudiant, bienfaiteur, membre du Conseil des gouverneurs et collaborateur du The University Magazine. Cet article traite en profondeur des liensculturels et de bénévolat que Edward Black Greenshields a tissés avec l'Université McGill, essentiellement à une époque où l'Université a pris une expansion considérable, soit entre 1890 et la Première Guerre Mondiale.

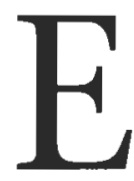
DWARD BLACK GREENSHIELDS was born in 1850 into wealth and privilege. A native of Montreal, he was the eldest son of Scottish immigrant John Greenshields, a prominent local dry goods merchant, and Mrs. E. (Elizabeth) Black Greenshields. ${ }^{1}$ After reviewing some of the literature on Canadian business men ${ }^{2}$ including Montreal's anglo-protestant community ${ }^{3}$ or the primarily Scottish business elite that inhabited Montreal's Square Mile, ${ }^{4,5}$ it might be supposed that close family, ethnic and religious ties and the pressures of family business interests, would lead
Edward to enter the family firm, to work hard, accumulate even more wealth and to return to the community a certain amount of his gains.

Indeed, while Edward Black Greenshields fits quite comfortably into the business leader and benefactor pattern, what sets him apart from most of his fellow Montreal businessmen and McGill donors, such as Lord Strathcona and William C. Macdonald, was his academic background. Unlike many of his business contemporaries he had a University degree. A McGill graduate actively engaged in the intellectual life of the University and his country, he

\footnotetext{
1 Montreal Gazette, 23 April, 1917; John Lovell, Lovell's Montreal Directory, 1918-1919, (Montreal: John Lovell and Son, 1918 ): 168. Mrs. E. Greenshields is listed as the widow of John Greenshields.

2 Michael Bliss, A Canadian Millionaire: The Life and Times of Sir Joseph Flavelle (Toronto: Macmillan, 1978): 308, 505-06.

3 Margaret Westley, introduction to Remembrance of Grandeur: The Anglo-Protestant Elite of Montreal, 1900-1950 (Montreal: Libre Expression, 1990).

4 W. Stantord Reid, ed., The Scottish Tradition in Canada (Toronto: McClelland-Stewart, 1976): 196.

5 Donald Mackay, introduction to The Square Mile: Merchant Princes of Montreal (Vancouver: Douglas and Mclntyre, 1987).
} 
published poetry and an article in The University Magazine, two volumes of art criticism and a slim tome of poems. He was the literary Renaissance man of the Montreal world of commerce.

Greenshields' burning interest in education and his intellectual engagement came from his background and his own experience as a student. There is a strong sense of rigorous, theological thought and a commitment to community service from his mother's side of the family, in the person of his grandfather and namesake Edward Black. Black, a minister of the Church of Scotland, had immigrated to Montreal in 1822. He served as a minister in the then pre-eminent Presbyterian Church in Montreal, the St. Gabriel St. Church. An evangelical minister, he was no stranger to the fractious and highly charged world of Montreal Presbyterianism. Black was one of three ministers in the church when a squabble erupted over the remuneration, or rather the lack of adequate financing, for the three clergymen. Black's faction occupied the Church and refused entry to their foes. An intervention from the Synod of the Presbyterian Church of Canada led to the formation of two separate churches in 1831. In 1834 Black became the first minister of the St. Paul's Presbyterian Church, a church whose congregation contained many representatives of Montreal's emerging business elite. This church, known by the 1880's as the "richest church" in Canada, was the religious home to many of the wealthy inhabitants of Montreal's Square Mile. St. Paul's remained the family church throughout Edward Black Greenshields' lifetime. Perhaps even more significantly Edward Black reflected or personified the importance and value of education to the family. In order to supplement the family's income, in the 1830's Edward Black had become a schoolmaster, setting up a short-lived private school in Montreal. A graduate of the University of Edinburgh, he received a Doctor of Divinity degree from the same institution in 1837.6

Young Edward Black Greenshields was educated locally in Montreal. He attended the High School Department of McGill College in the 1863-1864 session. ${ }^{7}$ The High School, perhaps better known as the High School of Montreal, had been founded in 1845 as a financial investment, with the goal of providing a "liberal course of education" to "enlarge the sphere of human knowledge ${ }^{\prime \prime}{ }^{8}$ It drew inspiration from schools in Edinburgh, as well as from English public schools such as Eton and Harrow. The classics-oriented curriculum was chiefly composed of Latin, Greek and mathematics courses with lesser emphasis on modern languages, history, geography, science, drilling and gymnastics. ${ }^{9}$ In 1853 the school became affiliated with McGill University and by 1863 had become a self-financing part of McGill.

The High School, with a staff of five teachers and about 200 students, was located in Burnside Hall, on the corner of Dorchester and University Streets and included a library and museum as well as lecture and meeting halls. ${ }^{10}$ The school served as a conduit to the college courses of McGill, supplying over half

6 George Woodcock, "Edward Black," in Dictionary of Canadian Biography, vol. 7, 1836-1850, (Toronto: University of Toronto Press, 1988): 77.

7 E.I. Rexford, The History of the High School of Montreal (Montreal: Old Boys Association of the High School of Montreal, 1950 ): 44.

8 Ibid., 30

9 Ibid., 46-49.

10 Ibid., 34-35.

11 Ibid., 54

12 McGill University, The McCill University Calendar and Examination Papers, 1865-1866 (Montreal, Lovell and Son, 1865), 11-12, 62-64. 
of the University's Arts graduates in the 1850's and $1860^{\prime} \mathrm{s}{ }^{11}$ Both Edward and his younger brother Samuel followed this route to McGill University.

The McGill University which Edward entered in 1865 was a relatively small, even an intimate, institution with 354 students. Arts was the second largest Faculty with a grand total of eighty students spread over the four-year program. Most of the students came from Quebec or Ontario, many from Montreal, while the remainder came from the Maritimes, save for one from New York. Thirty-three staft served the University, mainly in Medicine with only a few in Arts. ${ }^{12}$

When he graduated in 1869 , Edward's class totalled fifteen students. ${ }^{13}$ His classmates included two future professors of McGill, Francis Shepherd in medicine, who served as the Dean from 1908-1914, and Bernard J. Harrington, Professor of Chemistry and Mineralogy, a future son-in-law of the then Principal John William Dawson. Edward was an outstanding student: when he received his B.A. degree in 1869 he was also awarded the Prince of Wales Gold medal, with first rank honours in Mental and Moral Philosophy. ${ }^{14}$ Money to fund the prize had been donated by the Prince of Wales during the course of a visit to Montreal in 1860. In order to attain this reward Edward had to sit for a special set of examinations on logic, mental and moral philosophy as well as philosophy, both ancient and modern.

Whilc there is a dearth of information on the exact content of individual University lectures, one can derive from the reading lists and examination papers a fairly good idea of the subject matter. In this British-inspired curriculum, the classical Greek philosophers such as Plato and Aristotle were quite well represented while more "modern" European philosophers were also present, including John Hobbes, Kant, and Descartes. The textbooks came directly from authors in the British Isles, or indirectly through translations. ${ }^{15}$

Edward's chief tutor was the quietly effective William Turnbull Leach, educated at the University of Edinburgh, and an Anglican rector of St. George's Church. Leach had joined McGill in 1846 and held a variety of posts until his death in 1886 . He served a period as a Vice-Principal prior to John William Dawson's arrival as Principal in 1853, Dean of Arts from 1853-1886 and Professor of Philosophy and holder of the Molson Chair in English Language and Literature from 1872-1883, ${ }^{16}$ Leach had at one time been a Presbyterian minister but had left this Church over concerns for the legitimacy of the doctrine of pre-destination. Leach was, for John William Dawson, a McGill stalwart who had through his teaching, greatly aided the University. Leach had an abiding interest in classics of English literature, Chaucer, Shakespeare, Milton, and P'ope. ${ }^{17}$ As a teacher Leach encouraged the young lidward to explore literature and poetry but there is no written evidence of Edward's views on Leach. Leach may or may not have been an inspiring role model for the young Edward. However there are some themes,

13 MCGill University, The MCGill University Calendar and Examination Papers, 1869-1870 (Montreal: 1. C. Becket, 1869): 74-75.

14 McGill University, Directory of Graduates, Correcied to /uly 1913 (Montreal: Dodd-Simpson Press, 1913): 52; McGill University, The McGill University Calendar and Examination Papers, 1870-1871 (Montreal: John Lovell and Co., 1870): 73-74. The Prince of Wales Gold Medal was for an honours course in Logic and Mental and Moral Philosophy. Alfred Sandham, McGill College and its Medals (Montreal: D. Bentley and Co., 1872). Unpaginated.

15 McGill University, The MCGill University Calendar and Examination Papers, $1868-1869$ (Montreal, John Lovell and Co., 1868): 27-28.

16 Staff Card Index, entry for Edward Leach, n.d., McGill University Archives.

17 Edgar A. Collard, "Edward Turnbull Leach," in Dictionary of Canadian Biography, Vol. 11 (Toronto, University of Toronto Press, 1982): 503 . 
found in his later writings, which can be traced back to some of his undergraduate education: his tendency to reflect on the human condition, a keen interest in history as a set of distinct ages or epochs, and an inclination towards English authors and literature.

For many men of the Anglo-Montreal community, participation in the military formed an important part of their education, sense of societal responsibility as well as power, and Edward was no exception. He joined a local militia unit, the Third Victoria Rifles, and was on active service during the Fenian raids in $1866 .{ }^{18}$ In 1868 he attended militia school, received training from British officers, and became a second lieutenant in 1869 . He left the militia unit as a captain on February 12, $1875 .^{19}$

This military training occupied Edward only on a part-time basis: his chief occupation was the family business. In 1869 he commenced his apprenticeship in the family wholesale dry-goods business, $S$. Greenshields, Son and Co. ${ }^{20}$ His father and grandfather had founded the business but both had died by 1867 . He became a partner in $1876,{ }^{21}$ with his Uncle David Greenshields, who died in 1882. He then carried on the business with his only brother Samuel, who died in 1888. Edward became the head of the company in $1888^{22}$ and the president of Greenshields Ltd. in $1903 .^{23}$ He was responsible for the evolution of the company from a partnership to corporate structure. This concentration of dayto-day activities in the hands of employees allowed Edward to devote considerably more time to his benevolent and cultural interests. He, nevertheless, presided over the expansion of the business across Canada. ${ }^{2+}$ By 1907 the company was the country's largest supplier of both imported and domestic dry goods. 25

His views of Canadian political life were coloured by his business experiences. After all, he owned a trans-Canadian company with offices in Montreal and Vancouver. He believed that governments had clearly set-out responsibilities: low taxation, tariff protection, good government based on equitable, honest, tendering practices, and civic improvements, especially in the area of canals and harbours. ${ }^{26}$ Moreover, a cultural dimension, as revealed in his poetry, tempered this commercial view of Canada,

Farther than the eye can see, far north, far west, Stretched the prairie land, whose travail yields Such precious harvesting...

But Canada has fairer fields untold,

Where embryo thoughts and words of fire lie down, Resting until the master poet, skilled

To feed the hungry human heart, shall come God! For a ploughman, like the Scot of old

To draw a furrow through the teeming mould. ${ }^{27}$

He believed fervently in the 19 th century ideal of fostering Canadian national growth through the development of various educational and cultural institutions including universities, libraries and museums. His political ideas had other more conventional elements to it: for example he proclaimed, as President of the Montreal Board of Trade, the Anglo-

18 Montreal Gazette, April 27, 1917.

19 Record of Officers Ledger, 1862-1940, Victoria Rifles of Canada, Montreal Fonds, McCord Museum.

20 Montreal Gazette, April 23, 1917; C.W. Parker, ed., Who's Who and Why, vols. 6 and 7 (Toronto: International Press Ltd., 1914), 642 .

21 E. B. Greenshields, Diary, vol.5, 1913-1916, November 28, 1915, Greenshields Family Papers, McCord Museum.

22 Ibid.

23 Marcel Caya, ed., Guide to Archival Resources at McCill University (Montreal: McGill University Archives, 1985 ), 2: 171.

24 Ernest J. Chambers, The Book of Montreal (Montreal: The Book of Montreal, 1907): 175.

25 E.B Greenshieids, Diary, vol.1, 1894-1900, May 27, 1897, Greenshields Family Papers, McCord Museum. 
Saxon Empire to be the "greatest agency for good known to the world". ${ }^{28}$ His imperial ideals put him in good stead with the views of many others at McGill including Principal William Peterson, medical professor Andrew MacPhail and the humorist Stephen Leacock. Like many Canadians he saw no contradiction between his Canadian patriotism and attachment to Empire. The one both enabled and ennobled the other. However, this sense of bonding with the English speaking centres of London, New York and Toronto tended to exclude Montreal Francophones. ${ }^{29}$ While he certainly understood the French language, E. B. Greenshields reflected this tendency.

Directorships typify Greenshields' involvement in the Montreal business community: the Bank of Montreal, Royal Trust Company, and Standard Life Assurance Company, Ocean Accident Assurance Company and the Grand Trunk Pacific Railway. ${ }^{30}$ His own investment habits followed his directorships; his portfolio held mainly the stock of the Bank of Montreal and Royal Trust. ${ }^{31}$

The most time consuming role that Edward fulfilled at McGill was that of a volunteer member of the tightly knit Board of Governors.

Edward was named to the Board of Governors in 1886 and served until his death in $1917 .{ }^{32}$ He was a regular attendee of the Board Meetings and served on a variety of committees. His chief area of specialization was real estate or building management. Given that his dry goods business involved the management of land and warehouses on Victoria Square in
Montreal, it was probably a good fit. This benevolent work was often hands-on and wide-ranging: at times he was an executive, at times a manager and at times a supervisor. His tasks ranged from examining the cleanliness of the student union building, to helping to write the financial regulations of the University, to acting as a financial advisor concerning investments and signing deeds on the part of the University.

He was also a long-time member of the estate, or after 1908, the finance committee of the Board of Governors where most of the key economic decisions were made concerning the University's financial and business affairs, including managing the assets of the University. By 1900 McGill greatly expanded its scientific facilities especially in Engineering or as it was then known as "Applied Science", and Physics. Since 1893 new Physics, Engineering, Chemistry and Mining, and Library buildings and even more new laboratories were constructed. The development of these facilities was partly a result of the greater influx of gifts to McGill chiefly from two men who became chancellor (titular head) of McGill: the enigmatic tobacco magnate William C. Macdonald and Lord Strathcona (Donald Smith), Governor of the Hudson's Bay Company, President of the Bank of Montreal, and Canadian High Commissioner in London.

E. B. Greenshields regularly attended meetings of the estate committee with three or four other members. The mainstays consisted of Richard B. Angus, president of the Bank of Montreal, a direc-

26 E.B. Greenshields, Fiftieth Annual Meeting of the Montreal Board of Trade (Montreal: Gazette Printing Company, 1893): $11-12,16$.

27 Edward Black Greenshields, "The Fields of Canada", The University Magazine 8, no. 1 (1909): 126

28 Greenshields, Fiftieth Annual Meeting, 17, 24.

29 Roderick Macleod, "Salubrious Settings and Fortunate Families: The Making of Montreal's Golden Square Mile, $1840-1895$ " (Ph.D. diss., McGill University, 1997): 234.

30 Montreal Gazette, April 23, 1917.

31 Estate of E.B. Greenshields File, File 529, Greenshields Family Fonds, McCord Museum.

32 McGill University Archives, Staff Card Index, Entry for Edward Black Greenshields, nd. 
tor of the CPR, and art collector, Charles James or C.J. Fleet (BA 1873, Law 1879), solicitor of the Bank of Montreal, and a permanent secretary, usually the Bursar. Both large and small dealings concerning the financial lifeblood of the University passed before this committee.

The irrvestment decisions taken by this committee were quite conservative. The University purchased bonds but seemed to favour loans secured by land, including such clients as a Presbyterian church and a Catholic church. ${ }^{33}$ All demands for salary increases (academic and support staff) were set before the committee, including the payments of servants at the newly constructed Royal Victoria College. ${ }^{3+}$ No event at the University seemed too small to escape the notice of this committee, from the costs incurred during a flood at the Medical Building to the purchase of a few dozen chairs and stools in the Physics Building and the installation of new electric lights for teaching purposes in the Redpath Museum. ${ }^{35}$

In response to the growing administrative complexity of the University the committee carried out a number of reforms for the 1899-1900 year, including an appropriation system for all University expenditures. These new budget regulations allowed for the allocation of specific yearly budgets to the heads of twenty University departments, including seven laboratories. ${ }^{36}$ The donor regulations stipulated that there was to be no diversion of any gift or endowment from the purposes or department for which it was intended. ${ }^{37}$ The relationship of the University to the business world was also broached in this committee. By 1900 the McGill labs were being used extensively to do testing for commercial purposes and the benefits to the University of such relationships included receipt of the most up-to-date equipment and materials, charge-back of costs and exposure of staff in the most current practices in the field. However, there was a concern that this might prove to be a potential drain on University resources and the committee wished to see it "limited as much as possible to investigations of scientific interest or teaching value to students". ${ }^{38}$ Ultimately this evaluation was left up to the academic staff responsible for the labs.

Greenshields served as Honorary Treasurer of McGill from 1903-1911, and was primarily responsible for the onerous task of managing the finances for the reconstruction of two buildings, the Engineering Building and the Medical Building, which had burned in 1907. By all accounts he did yeoman work in the management of these financial resources. ${ }^{39}$ He dealt with suppliers, insurance companies and William C. Macdonald who provided funds for the Engineering Building as well as Lord Strathcona who financed the new Medical Building.

The relationship of academia with businessmen on the Board of Governors was a question that Greenshields touched upon in a humorous speech at a Faculty of Arts dinner in the Faculty Club in 1909. After remarking to professors that he seldom had the

33 Estate Committee minute book, June 13, 1901 McGill University Archives, Board of Governors, RG 4, C 0289 , File 09038.

34 Estate Committee minute book, September 14, 1899, MCGill University Archives, Board of Governors, RC 4, C 0289 , File 09038.

35 Estate Committee minute book, December 12, 1901, McGill University Archives, Board of Governors, RG 4, C 0289 , File 09038.

36 Estate Committee minute book, April 1999, McGill University Archives, Board of Governors, RG 4, C 0289 , File 09038.

37 lbid.

38 Estate Committee minute book, June 13, 1901 McGill University Archives, Board of Covernors, RG 4, C 0289 , File 09038

39 Board of Governor's minute book, 1910-1919, April 23, 1917, McGill University Archives, Board of Governors, RG 4, C 0008, File 09008 .

40 Speech - Health of Andrew MacPhail at a dinner at the Faculty Club, 10 March, 1909, Greenshields Family Fonds, File 519, McCord Museum. 
opportunity to talk to academics because he was usually the listener, he explored the differences and associations between academia and merchants. ${ }^{40} \mathrm{He}$ felt poets and writers were needed, through their "winged words", to inspire merchants, often holders of prosaic knowledge, to greater intellectual heights. Although poets were not supposed to understand business, Greenshields suggested (quoting Plato) that "Poets utter great and wise thought, which they do not themselves understand". He postulated that poets are indeed qualified to write about business. Therefore, he asked that poets utter their great and wise thoughts and merchants do the understanding. ${ }^{41}$ Lastly, he suggested that merchants too have ideals ancl dreanns beyond their commercial aspirations, "The dreamers rule the world, ever since Joseph (and even before him) dreamed his dreams and cornered the wheat market". ${ }^{42}$

In a similarly humorous vein, the view of a Faculty member concerning the Board of Governors was read out at another Dean of Arts' dinner, October 29, 1909:

First let me voice a wish I must avow, The Board of Governors might see us now. That we might have to make the tale complete An Angus, Greenshields and a Fleet. Oh Sirs, this spectacle would make them feel That poor professors like a solid meal... When next the stream of benefaction starts, Pray pour it on the Faculty of Arts. Oh, Edward, William, Robert, James and Joln Delay no longer, kindly turn it on!
This poem was supplied courtesy of McGill professor, and noted Canadian humorist Stephen Leacock. ${ }^{43}$

On a more serious note, Greenshields saw Universities as intellectual centres for teaching and research helped by merchants but run by its Faculty. This balanced view of Universities contrasted sharply with the view expressed to him by his friend William Cornelius Van Horne, "Universities... should not be object of charities .... Higher education should be of the best quality and adequately paid for: indeed I believe that our great schools and universities will never reach the maximum of usefulness until they are run like joint stock companies and on business principles. Then we shall see a struggle to secure the highest class of instructors with the most perfect of equipment and see the end of the middle age traditions which now govern most of the great institutions of learning ${ }^{\prime \prime 4}$.

In his family life as well, Greenshields remained connected to the University. In April 19, 1876 he married Eliza Brodie, ${ }^{45}$ youngest daughter of Reverend John Cook, and they had two children, Edward John Moray ${ }^{46}$ and Elizabeth Muriel. ${ }^{47}$ The Reverend John Cook was the Presbyterian minister of St. Andrew's Church in Quebec City and the Principal of Morin College from 1860-1892. Morin College was an affiliate of McGill University until its closure in 1900, and presented students in the Faculties of Arts and Divinity (Presbyterian Church). ${ }^{48}$ Edward, therefore, had not only been a student of

\footnotetext{
41 Ibid.

42 Ibid.

43 Stephen Leacock, Box 2, File 1, Greenshields Family Fonds, McCord Museum

44 Letter from William C. Van Horne to E.B. Greenshields, December 27, 1909, William C. Van Horne Fonds, MC2013, McGill University Archives.

45 E.B. Creenshields, Diary, vol.5, 1913-1916, November 28, 1915, Greenshields Family Fonds, McCord Museum.

46 Montreal Gazette, 23 April 23, 1917

47 Marcel Caya, ed., Guide to Archival Resources at McGill University (Montreal: McGill University Archives, 1985 ), $3: 324$.

48 Ethel L. Gale, "Morin College, Quebec," The McGill News 11, no.4 (September 1930): 12-15.
} 
McGill's High School and University, he had actually married into the institution.

Edward's time given freely to the University through service on various committees, was also supplemented by monetary donations, chiefly through legacies. These activities spanned from the 1880 's up to at least the 1960's and it became very much a family tradition. Edward's younger brother Samuel died in 1888, and left a bequest to McGill, as well as to the Montreal General Hospital and St.Paul's Church. ${ }^{49}$ Both Edward and his company, Greenshields Ltd. provided generous donations to the Centennial campaign of 1921. Edward's son, Edward John Moray Greenshields, left McGill money to be used for research in the Faculty of Medicine to honour his father's name. ${ }^{50}$ The archival records of the family, including Edward Black Greenshields' diaries, were left to the McCord Museum. Edward's daughter, Muriel Drinkwater, donated some of his paintings to McGill in the 1960 's. ${ }^{51}$

Aside from these legacies, Edward provided, during his lifetime, sums of money for particular projects, including the E.B Greenshields Prize for the best summer essay written by a student in Applied Science (1891-1898) 52 ; and in 1904-1905 Edward provided money to McGill Librarian Charles H. Gould to aid in the financing of McGill's Library School. Gould specifically thanked Greenshields and four other benefactors who "through their generosity relieved the University of the pecuniary obligations incurred in conducting the school" 53
Greenshields' pet McGill project was the initiation of a University publication devoted to worthy scientific and literary papers from the University community. With science professors John Cox and Henry Taylor Bovey, he lobbied the University's governing academic body, the Corporation, to set up such a publication in $1896 .{ }^{54}$ The result of this lobbying was the McGill University Magazine, which ran from to 1901 until 1906 but there is little information on Greenshields' further involvement with this undertaking. However, Greenshields' relation with its successor, The University Magazine, was another matter.

The University Magazime was a joint publication of McGill, Dalhousie and the University of Toronto, set up to examine current Canadian issues in science, arts, philosophy, politics and industry. Despite the triumvirate of Universities involved, everyone from S.E.D Shortt, in his study of Andrew MacPhail, to Stephen Leacock's contemporary assessment, attributes the success and tone of the magazine to the editor and McGill medical professor, Andrew MacPhail. 55 MacPhail was well known for his strong imperialist sentiments, acerbic criticisms, sometimes-polemical writing style, anti-American sentiments, and lack of sympathy for reforms. According to Shortt, MacPhail had a "reverence for tradition and the moral dimension of life, based on the legal, cultural and religious conventions associated with a British heritage and was hostile to the excesses of technological innovation and democracy", ${ }^{56}$ As Greenshields pointed out, MacPhail was also famous for his epigrammatic

\footnotetext{
49 Letter from E.B. Greenshields to J.H.R. Molson, Chair, Estate Committee, McGill University, May 11, 1896 McGill University Archives, Board of Governors, RC 4, C 0503, File 6771

50 McGill University Archives, RG 4, Board of Covernors, C.0260, file 7272, E.B. Greenshields - Estate file.

51 lbid.

52 E.B. Greenshields Prize file, McCill University Archives, Board of Covernors, RG 4, C 0074, File 10307.

53 McGill University, Annual Reports of McGill University, Report 1904-1905, 33.

54 Letter of John Cox to Charles Could, January 21, 1896, McGill University Archives, RG 40, C 0003, File 01490.

S5 S.E.D. Shortt, The Search for an Ideal: Six Canadian Intellectuals and their Convictions in an Age of Transition, 1890-1930 (Toronto: University of Toronto Press, 1970): 16-17.
} 
remarks, which were not always encouraging for would-be writers, such as "nothing worth writing between a dictionary and poetry "and "no one can write prose unless he is a poet". 57

While Greenshields may have shared some of Macphail's views on a romantic idealized agricultural past, or certainly some of his imperial sentiment, he shows no signs of ever being critical of technology and he eagerly embraced every new technological innovation from the telephone to the automobile and spent much of his benevolent work at McGill promoting science and technology. Nevertheless, Greenshields became an admirer of Andrew MacPhail and enthusiastically supported The University Magazine. At a Dean of Arts Dinner honoring Andrew MacPhail in 1909, he called it one of the best magazines published anywhere praising its "concise and pungent" style. ${ }^{58}$ For Greenshields the magazine represented an attempt to bring together the increasingly disparate elements of University life, especially in the area of research. Like most leading research institutions McGill was becoming increasingly specialized employing many experts knowledgeable in particular areas but less concerned with the overall relationship of the parts. Probably recalling his own educational experiences under Edward Leach, Greenshields valued the generalist who could provide a global perspective. Greenshields found in Andrew MacPhail a person who could examine both the work of Principal William Peterson on Cicero and the scientific work of Rutherford and assemble this material for discussion in a literary forum. ${ }^{59}$
Greenshields published at least four poems and one review article in The University Magazine. Most of his poetry was then re-published in a volume entitled Poems in 1910. The published poetry was imbued with the same sense of romanticism, which guided his analysis of paintings. However, there was much reflection on the vagaries and mysteries of life. His fascination with the power of nature is reflected in poems like "A Summer Day", through lines such as,

Oh nature, stay thy wandering here

While the sea whispers in my ear

Wrap us in the great calm and rest ${ }^{60}$

His empathy with the tranquil, often-sad human figures appearing in the Dutch Hague School paintings is reflected in the poem, "A Painting by Matthew Maris" where he envisions what a lonely woman might be contemplating:

With down-dropt eyes that gaze far, far away She pauses in the old cathedral aisle, And just the shadow of a lingering smile Tums onto troubled thought and will not stay Dreams of the future haunt her anxious mind 61

The poems submitted to the magazine passed through the eager editorial hands of Andrew MacPhail. As MacPhail wryly noted to Greenshields, he enjoyed the chance to look at poetry before publication because it "compels him to enjoy it" when it is good.

56 Ibid., 20 .

57 Speech - Health of Andrew MacPhail at a dinner at the Faculty Club, March 10, 1909, Greenshields Family Fonds, File 519 , and McCord Museum.

58 Ibid.

59 Ibid.

60 E.B. Greenshields, Poems (Montrea 1: s.n., 1910).

61 Ibid. 
VOL. VII., No. 3.

OCTOBER : 5908
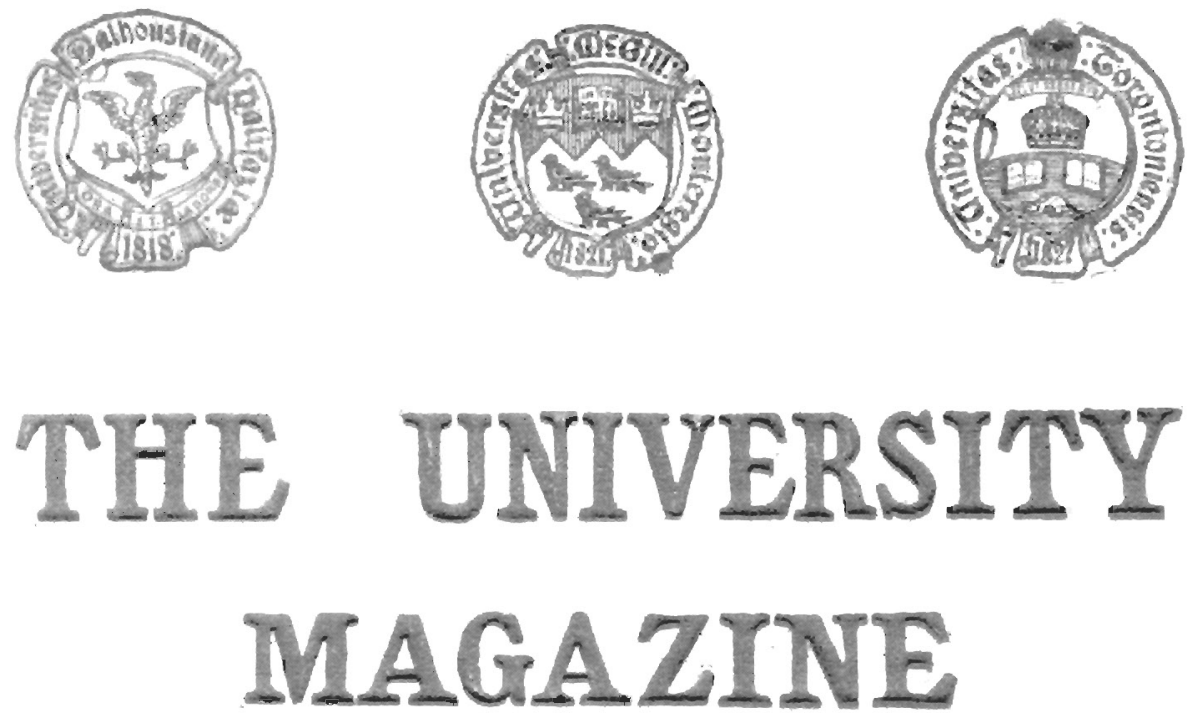

\section{OCTOBER 1908}

I. A FORGOTTEN POHT-E. B. GREENAHIEIDA

11. COOPERATIOA IN HTSTORICAL RESEARCH--LAwRACE J. BurpeE

HI. THE MANX MANSIONGD HOLSF-FDWARD W. THOMSOA

I6. THE SOUTH AKRICAN SITUATION-H. S. DENNY

V. BRITISII DIPLOMACX AND CANADA: ILI. OREGON AND SAN JUAN BOUNDARLES-JAMES WHTE

TARIFFS. BOTNTIFS. A.VD THE FARMER-W.C.GOOD

WI. MANUFACTLRES AND SIIPPING-ARChIBALD MCGOUN

1.11. QUEBEC-JOHN MOCRAR

1X. A STUDY IN IMPERIALISW-KEITH G. FIELING

X. ALICE IN WONDERLAND-ARchibald MacMechan

XI. A. OLD WOMAN-MARJORY MACMURCHY

XII. THE EJOLUTION OF RELIGION-E. W. MACBRIDE

Figure 1. The University Magazine, 1908 (McGill University Archives). 
${ }^{62}$ MacPhail was particularly impressed Greenshield's insights, in particular the verse:

Life without its dreans? Ah, then

Senseless is all the work of men

On a dreamless earth ${ }^{63}$

Writing to Greenshields about the verse, MacPhail remarked that Greenshields found more freedom through his work than "I (Macphail) have yet seen but also it ironically gave him a new perception on the limits of this freedom." 64

Greenshields also published an article in The University Magazine (Fig. 1) on the English born Canadian poet Charles Heavysege. Heavysege (1816-1876) arrived in Montreal in 1853 and supported himself chiefly as a journalist and editor with the Montreal Daily Witness newspaper. His most famous work was the long verse drama "Saul" based on the biblical story of King Saul, published in $1857 .{ }^{15}$ Greenshields' cogent analysis of Heavysege as a poet of great insight but hampered by an inconsistent technique, especially evident in "Saul", echoed other later critiques of the poet. ${ }^{66}$

Greenshields was far more enthusiastic about Heavysege's shorter poems, which echoed Shakespearean sonnets and in which the poet's use of "nature" themes came to the fore, for example in "The Stars":
And as I gazed on the field sublime

To watch the bright pulsating stars

... the horloge of time

... From the ancient hour of prime ${ }^{67}$

Greenshields' attraction to Heavysege as a subject was at least partly based on the poet's connection to romanticism but it also represents a quest to revive, or perhaps preserve for posterity, this forgotten fragment of Canadian culture.

Greenshields' support for The University Magazine led him a new career as a fundraiser for this seriously under financed publication. In 1909 he lobbied various members of the Board of Governors and some other supporters to help pay off the mounting debts of the magazine, appealing to these potential benefactors to keep the magazine afloat in the interest of literature and education in Canada. ${ }^{68}$ He was fairly successful, save for his fellow art collector and friend William Cornelius Van Horne, the mercurial former President of the CPR, who refused to con tribute even more to the magazine that, as he stated quite emphatically, had "a limited circulation, did not charge enough for subscription and should pay for itself." Greenshields wisely cut his losses, told Van Horne he would recommend the rate be increased, that he would not ask Van Horne for more funding but could he not supply the same amount as last year. Van Horne did just that ${ }^{69}$ Typically, Greenshields down-

62 Letter to E.B. Greenshields from Andrew Macphail, ca.1909, Greenshields Family Fonds, File 493, McCord Museum.

63 lbid.

64 Ibid.

65 J.C. Stockdale, "Charles Heavysege," in Dictionary of Conadian Biography, vol. 10, 1871-1880 (Toronto: University of Toronto Press), 347-48.

66 E.B. Greenshields, "The Forgotten Canadian Poct," The University Magazine, 7, no, 3 (October, 1908): 353 In discussing Heavysege's epic work Saul, Greenshield's comments that "Though the drama as a whole is too prolix (tedious) and lacks dramatic power, it contains many passages of remarkable imagination and great poetic beauty". In Stockdale's entry on Heavysege, (supra, note 65), the poet's works are "grand (mainly) in conception, full of a keen understanding of human nature, but often spoiled by the author's lack of self-criticism, which lead him to beauty to incongruity." (347)

67 E.B. Greenshields, Poems (Montreal: n.d., 1910).

68 Letter from E.B. Greenshields to William C. Van Horne, 8 December, 1909, William C. Van Horne Fonds, McGill University Archives, MG 2013 
played his role in helping the magazine and publicly gave all the credit for the temporary financial rescue of the magazine to the Dean of Arts, Charles Moyse. The magazine did fold in 1920 putting an end to its chronic funding problems; according to Greenshields it was "financially speaking... conceived in poverty and nourished in neglect".70

A good deal of Greenshields' time after 1900 was devoted to his literary career as an art critic, his poetry and to collecting art. There are three main ideas, which run through his concept of art and poetry: firstly, an intense personal romanticism; secondly, an acute sense of the importance of the sublime; and thirdly, a firm belief in the link between poetry and art.

In the last quarter of the 18th century Romanticism, which included a belief in the redeeming qualities of nature, arose in reaction to social conditions of the time. In the arts Romanticism emphasized the individual and the natural, showing less concern with the ideal and the classical form. Value was placed on the artist's personal, often emotional interpretation of nature. Landscape painting became the means of revealing the artist's most significant and intense reaction to life. The personal, subjective view of the artist to the tragedies and joys of nature was to be revealed on the canvas for observers to understand.

The fascination with nature included the idea of the sublime. The best known British art critic of the 19 th century, John Ruskin, defined the sublime as "anything that elevates the mind. This elevation is caused by the contemplation of greatness. Related to the noblest things". ${ }^{71}$ This re-thinking of the value of art, as more than the contemplation of a beauti- ful object or classical form was also connected to a re-evaluation of poetry in relation to art.

It is not surprising that these thoughts echo throughout the poetry and art criticism of Edward Black Greenshields, since he knew the work of John Ruskin well and greatly admired the landscape paintings of Turner. ${ }^{72}$ A succinct representation of Greenshields' artistic ideals can be found in his poem entitled "Art":

Art is the expression of the inner thought

In outward beauty of unspoken word

And man in patient labor must be taught

The means by which its spirit may be heard. ${ }^{73}$

This subjective view of art did not merely extend to Tumer but was applied by Greenshields to major schools of European landscape art in the 19th century. In the course of his two major works on art, The Subjective View of Landscape Painting (1904) and Landscape Painting and Modern Dutch Artists (published in 1906) he rigorously applied the criteria of romantic, landscape and emotional relevance to artistic works of several schools of landscape art.

In his analysis of landscape painting, Greenshields sought works that demonstrated to the observer the beneficial effects of nature, the impact of experiencing the sublime as a type of personal and expressive liberation, or perhaps even a mystical experience. He placed great emphasis on an emotional reaction to the content filtered through more concrete criteria such as form.

In Greenshields' opinion, great paintings should make their observers stop and reflect upon the work in both a technical and intuitive way. Analysis of a painting went beyond an attraction to its colours or

69 Letter from E.B. Greenshields to William C. Van Horne, December 29, 1909 and Letter trom Van Horne to Greenshields, January 2, 1910, William C. Van Horne Fonds, McGill University Archives, MG 2013.

70 Speech - Health of Andrew MacPhail at a dinner at the Faculty Club, March 10, 1909, Greenshields Family Fonds, File 519, McCord Museum.

71 Andrew Wilson, Turner and the Sublime (London: Published by British Museum Publications for the Art Callery of Ontario, the Yale Center for British Art, the Trustees of the British Museum, 1980): 68-69.

72 E.B. Greenshields, Diary, vol. 1, 1894-1900, January 15, 1895, Greenshields Family Fonds, McCord Museum

73 E.B. Greenshields, Poems (Montreal: n.d., 1910). 
subject: contemplation of a painting comprised two interrelated parts: examination of the techniques through which the form of the painting was presented (use of colour and balance) followed by the personal vision of the artist which inspired the painting's creation. Subjective art in the form of landscape painting should provoke a "feeling of pleasure and content by its beautiful colour and form and its technique, it should reveal the poetry and imagination of the artist's vision, and it should communicate his thought and feeling with those in sympathy with this idea"74. The goal of subjective landscape painting was not to imitate nature but to show the effect produced by nature on the artist.

In his two books of criticism, Greemshields traced the development of landscape painting from the Renaissance to the beginning of the twentieth century. He identified Claude Lorrain (1600-1682), as one of the pioneers of landscape art because of his emphasis on landscape over human figures and his focus on nature for its own sake. ${ }^{75}$ In Greenshields' opinion, English landscape artists John Constable (1776-1827), and J.W.M. Turner (1775-1851) added an important new dimension to the subjective approach. Constable gave to landscape art the ability to re-create an authoritative out-of-doors atmosphere, but it was the English artist J.W.M. Turner who drew Greenshields' highest praise, calling him the most imaginative landscape painter in the world. ${ }^{76}$ He then turned to France in the 1830 's. The Barbizon School's revolt against Classicism was exemplified by the work of J.C.C. Corrot, who portrayed the countryside as an "idealised, personal and poetical revelation to the world, ${ }^{177}$ The quali- ties which these artists shared with the most recent (1900) approach to Iandscape, the Dutch Hague School, was a love of nature and an individualistic expression of their art. ${ }^{78}$

Greenshields portrayed the evolution of landscape painting as a series of progressive steps through history, up to the great artists (ca. 1900) of the Hague School. But the French Impressionists, who painted landscapes in an individualistic and subjective way, did not meet with his approval. While Greenshields praised the quality of Impressionist painting, describing "the mixing of brilliant colours which gave a bright and beautiful quality of vibrating air", he passed quickly over the group, minimizing its importance, and calling their work an "incomplete and transitional form of art" ${ }^{79}$

Although Greenshields never discusses in detail why he did not favour the Impressionists, in his technical analysis of art, he placed a great deal of emphasis on the interplay of light and shadow. In his eyes, perhaps the Impressionists' tendency to ignore this convention diminished their importance.

Greenshields extolled the Hague School of Dutch artists as the finest expression of the subjective view of landscape painting. The seven principal artists of the Dutch Hague School were Johannes Bosboom, Joseph Israels, the Maris brothers James, Matthew and William, along with Anton Mauve and J, $\mathrm{H}$. Weissenbruch. These men revealed "nature and their own feelings unconsciously inspired by nature... with a spark of the divine power of genius." 80 They depicted ships, peasants, canals and farm animals but nature always dominated the scenery. In particular he admired their ability to play with both light and

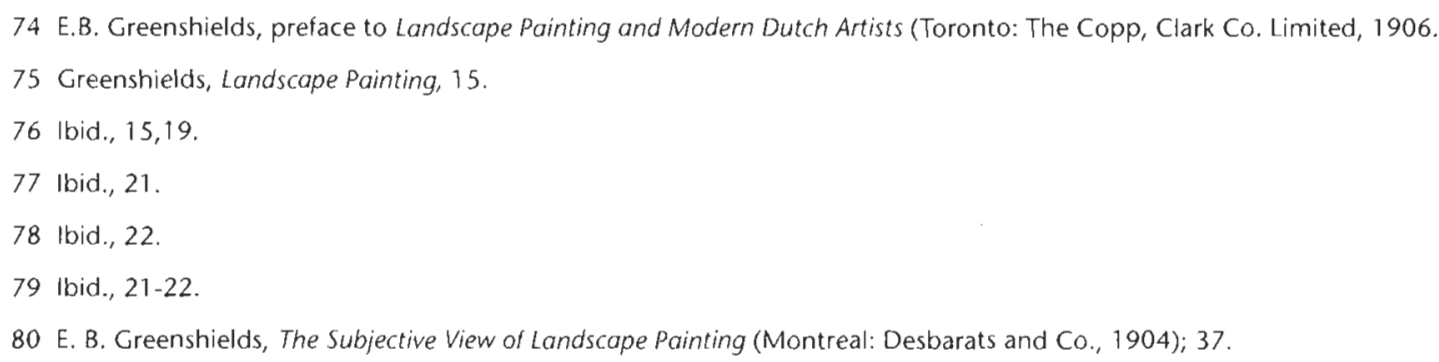


atmosphere, mainly in darkish grey and brown tones but at times in brilliant colour. ${ }^{81}$

Josef Israels, the founder and leader of the Hague School specialized in the depiction of peasant life. For Greenshields the simple and spiritual messages of Israel's work were enhanced by a fine use of techniques. For example, in the "Girl in the Cottage" he was fascinated by the effect of diffused light passing through the window into the room but he also emphasized the effect on the observer, "We like to watch the girl sitting quietly there, with the light falling in bright ray: we wonder what were the dreams that were passing through her young mind as she sat there alone." 82

Some of the group's members specialized in painting particular subjects. Anton Mauve concentrated on tranquil pastoral settings while William Maris focused on cattle in meadows and ducks in river settings. Greenshields' analysis of William Maris' work reveals some of his own underlying attraction to the Hague School; he perceives Maris' life and art as being "liee of the stress and fever of modern times" and a "breath of refreshing country air" ${ }^{83}$ ln a similar vein he envied the greatest Hague school painter J. H. Weissenbruch tor his "simple life completely occupied with the art he loves". ${ }^{84}$ This yearning for a simpler, more bucolic, tranquility appealed to Greenshields, awash in the hurly burley of industrial Montreal.

Greenshields' preferred painter of the Hague School was J.H. Weissenbruch. He declared him to be the purest landscape or seascape artist, as someone who could communicate the "mystery solitude and vastness of nature as well as "the littleness of humanity and weary labours of man" 85 . His technical abilities, consisting of the "skilful composition of beautiful forms and graceful lines ... the atmospheric sky. Absolutely right tones throughout." 86 was matched only by his enjoyment of the simple brooding scenes from nature.

Greenshields major work of criticism, Landscape Painting and Modern Dutch Artists (1906) was in essence an expanded version of his previous work, The Subjective View of Landscape Painting. Both books were written for the general public from a layperson's point of view. Contemporary critics of the book cited his simple unpretentious style, linkage of poetry with art, his obvious sincerity and heartfelt commitment to art and his critical commentary. ${ }^{87}$ Writing in 1989 about his books, Janet Brooke stated that Greenshields' overwhelming interest in the Hague School and lack of interest in works reflecting the aesthetic tastes of other turn of the century Montreal collectors, had created the false impression that all Montreal collectors specialised in the Hague School. In fact, as she points out, Richard B. Angus, George Drummond and William Cornelius Van Horne collected very widely and the latter two held artwork by the Impressionists. ${ }^{88}$

Greenshields' steadfast views on the Dutch Hague School undoubtedly had an impact on the Montreal art milieu. Greenshields and many other collectors

81 Greenshields, Landscape Painting, 114-15.82 lbid., 143.

82 lbid., 143.

83 bid, , 178

84 bid. 182

85 Greenshields, Subjective Landscape Painting, 58

86 Greenshields, Landscape Painting, 186.

87 Greenshields Family Fonds, File 508, Book Reviews, 1906, McCord Museum. The file contains book reviews from several sources in 1906 including The New York Times, Professor James MacNaughton and The Philadelphia Public Ledger. 
acquired the more conservative works emanating from the French and English academic schools, the Barbizon School and the Hague School, and largely ignored the Impressionists. ${ }^{89}$ As a prominent member of the Exhibits Committee of the Montreal Art Association he encouraged the exhibition of more traditional works. ${ }^{90}$

Greenshields' enthusiasm can be explained by several factors: firstly, when he wrote about and collected the School's work, its reputation was at its zenith; secondly, as a collector he had a vested intelest in the school; and thirdly, and most importantly, he had a deep and profound aesthetic attachment to the works of the school because they appealed to his core intellectual beliefs. While Greenshields wrote a very sympathetic defence of the Hague School, however, his hope that it would be considered as one of the major schools of European art did not come to pass.

Like many of his fellow businessmen, Greenshields was interested in promoting education and cultural institutions. A prominent member of
McGill's Board of Governors from 1887-1917, he was the Honorary Treasurer from 1903-1910 during a period of financial crisis brought on by destructive fires at two buildings, and a member of various financial or management committees. Greenshields' preoccupation with art and literature lead him to be more engaged in the intellectual life of the university then his other, more business-oriented, colleagues on the Board of Governors.

The links to McGill of Edward Black Greenshields are many and varied. He contributed to the life of McGill as a student, benefactor, financial advisor, business executive and intellectual. In 1910 Greenshields was presented with an Honorary Doctor of Laws degree. Nominated by his colleagues on the Board of Governors, Charles J. Fleet and Dean of Arts Charles Moyse, the reasons for this award were cited as "his distinguished position in the conmunity, his services to the University and his interest in Art and Literature". ${ }^{91}$ It was a tangible recognition of his multifaceted role within the McGill community and beyond.

88 Janet Brooke, Le Gout de L'Art: Les collectionneurs Montrealais 1880-1920(Montréal: Musée des beaux-arts de Montréal, 1989 ): 29.

89 Marta H. Hurdalek, The Hague School: Collecting in Canada at the Turn of the Century (Art Gallery of Ontario, 1984): 13. Between 1879 and 1914 the Montreal Art Association mounted eighteen exhibits, featuring mainly Old Masters, Barbizon and Modern Dutch painters, including the Hague School. Only William Van Horne and Sir George A. Drummond were collectors of Impressionist painters. (Brooke, Le Gout de l'Art, 22,24)

90 Hurdalek, The Hague School, 16; Brooke, Le Gout de L'Art, 29. In 1900 he was on the organizing committee for the annual exposition. The theme was the Hague School (29). Greenshields held many other posts within the Association including the Art Gallery Committee, from 1887 to 1890, the Finance and House Committee, 1887-1890 and the Treasurer from 1888-1890 (Art Association of Montreal, Report of the Council to the Association, Montreal: D. Bentley and Co., Reports 1887-1890).

91 Board of Governor's minute book, 1910-1919, April, 23 1917, McGill University Archives, RG 4, C 0008, File 09008. 